\title{
CRYOPROTECTIVE AGENTS AFFECT AMINO ACIDS INCORPORATION INTO TOTAL PROTEINS IN CELLS OF LYMPHOID ORGANS AND LIVER OF EXPERIMENTAL ANIMALS
}

\author{
A. K. GULEVSKYY凶, YU. S. AKHATOVA, A. Yu. NIKOLCHENKO \\ Institute for Problems of Cryobiology and Cryomedicine, \\ National Academy of Sciences of Ukraine, Kharkiv; \\ 凶e-mail: profgulevskyy@gmail.com
}

Received: 07 July 2019; Accepted: 25 June 2020

The effect of penetrating (glycerol, DMSO) and poorly penetrating (PEG-400) cryoprotective agents on labeled amino acids incorporation into de novo synthesized proteins in the cells of mice thymus, lymph nodes, spleen and cell-free rat liver extract was studied. Cryoprotective agents within the range of concentrations which provide a cryoprotective effect were found to inhibit significantly protein synthesis in cell-free systems under investigation. The most effective inhibition was exerted by polymeric cryoprotective agent PEG-400. Cryoprotective agents more efficiently inhibited protein synthesis at a cell level as compared with that in cell-free system that was likely associated with their effect on amino acids transport system. An inhibitory effect of cryoprotective agents on the protein synthesizing apparatus of cells was determined to be $\mathrm{Mg}^{2+}$-dependent and reversible.

Keywords: cryoprotective agents, incorporation of labeled amino acids, protein biosynthesis, cell-free system, lymphoid organs, $\mathrm{Mg}^{2+}$-dependent.

$\mathrm{T}$ he substances capable of protecting the living tissues against damaging effects of low temperatures, i.e. cryoprotective agents (CPAs), were reported to pseudotoxically affect the cryopreserved cells and tissues. This influence consists in a reversible inhibition of their functions and metabolism [1-4]. As well according to the published data [5-7], a toxic effect of CPA is owing to their interaction with membranes, that disorders the transport properties of plasma membranes and mitochondria, leading to a change in ionic homeostasis and metabolic state of cells. The binding of CPAs to macromolecules and their complexes causes their partial dehydration, resulting in an alteration of spatial structure of macromolecules, their reversible denaturation and impaired enzymatic activity [7].

Modern data show that even in low concentrations the CPAs affect somatic and reproductive cells [8-10]. In this regard, the question of the CPAs influence on metabolic processes in cells and tissues is getting relevant, especially in view of the development of such areas in medicine as cell and tissue therapy as well as assisted reproductive technologies [8-10]. Moreover, recently many authors have demanded the re-considering of using the CPAs in reproductive technologies, as modern experimental results demonstrate that CPAs within a wide range of concentrations have a toxic effect at the genome level, which leads to irreversible impairments in structure and functions of cells [8-10]. Earlier, we have found that CPAs inhibit the transport of amino acids into Ehrlich ascites carcinoma cells, as well as the aminoacylation [11, 12]; in this regard, we could assume that they also influence protein biosynthesis at the translation level.

This research aim was to investigate in vitro the effect of penetrating (glycerol, DMSO) and poorly penetrating (PEG-400) CPAs on incorporation of la-

(c) 2020 Gulevskyy A. K. et al. This is an open-access article distributed under the terms of the Creative Commons Attribution License, which permits unrestricted use, distribution, and reproduction in any medium, provided the original author and source are credited. 
beled amino acids into de novo synthesized proteins in the cells of thymus, lymph nodes, spleen, and rat liver cell-free extract.

\section{Materials and Methods}

Isolation of lymphoid cells. Suspensions of thymus, spleen and lymph nodes of male outbred mice were obtained with Eagle's medium, buffered with $10 \mathrm{mM}$ Tris-HCL, pH 7.4. Lymphoid organs were crushed with scissors, passed through several layers of nylon tissue and subjected to easy homogenization. Cell suspensions were removed to tubes and centrifuged for $10 \mathrm{~min}$ at $2500 \mathrm{~g}$. The cell pellet was re-suspended in a portion of fresh medium. Cell viability using eosin staining was $89-94 \%$.

Measurement of incorporation of ${ }^{14} \mathrm{C}$ amino acids in isolated cells of lymphoid organs. After obtaining the cells were suspended in Tris-saline buffer (0.15 M NaCl, $10 \mathrm{mM}$ Tris-HCl, $\mathrm{pH}$ 7.4) at the rate of 50 million cells per $\mathrm{ml}$ of solution, $1 \mu \mathrm{Ci} / \mathrm{ml}$ of ${ }^{14} \mathrm{C}$-amino acids of chlorella protein hydrolyzate was added (specific activity $10.4 \mu \mathrm{Ci} / \mathrm{ml}$ ) and incubated at $37^{\circ} \mathrm{C}$. The incubation time when studying the incorporation of 14C-amino acids into total proteins was $15 \mathrm{~min}$. To wash the amino acids not incorporated into proteins, the samples were cooled after incubation, $3 \mathrm{ml}$ of cold 5\% TCA were added, homogenized and heated at $90^{\circ} \mathrm{C}$ for $30 \mathrm{~min}$ to decompose the nucleic acid, after that the samples were cooled down to $0^{\circ} \mathrm{C}$, applied to nitrocellulose ultrafilters (Whatman, USA) and sequentially washed, namely 3 times with $70 \%$ ethanol at $42^{\circ} \mathrm{C}$, twice with a mixture of alcohol-chloroform (1:1) and twice with chloroform. The filters were dried and radioactivity was counted in a standard toluene scintillator with an Intertechnick SL-40 scintillation counter (France).

Slicing of rats' liver. The study was performed in outbred male white rats. To obtain liver sections, the method was used as follows [13]: liver was placed between two frosted glasses and cut with a blade fixed in a special tripod, which allows the obtaining of 1-2 mm sections. Sections were incubated with $2 \mathrm{ml} \mathrm{Krebs-Ringer} \mathrm{bicarbonate} \mathrm{buffer:} 0.9 \%$ $\mathrm{NaCl}, 1.15 \% \mathrm{KCl}, 1.22 \% \mathrm{CaCl}_{2}, 2.11 \% \mathrm{MgSO}_{4} \cdot 7 \mathrm{H}_{2} \mathrm{O}$, $1.3 \% \mathrm{KH}_{2} \mathrm{PO}_{4}, 1.3 \% \mathrm{NaHCO}_{3}$ neutralized with $\mathrm{CO}_{2}$ to $\mathrm{pH} 7.4$ and aerated with a gas mixture of $95 \% \mathrm{O}_{2}$ $+5 \% \mathrm{CO}_{2}$ for 10 minutes, after which $1 \mu \mathrm{Ci} / \mathrm{ml}$ of ${ }^{14} \mathrm{C}$-amino acids of chlorella protein hydrolyzate was added to the samples $(10.4 \mu \mathrm{Ci} / \mathrm{ml}$ specific activity) and incubated for $1 \mathrm{~h}$ at $37^{\circ} \mathrm{C}$. Next, the biosynthesis was stopped by placing the samples in an ice bath.
The incorporation of ${ }^{14} \mathrm{C}$ amino acids into proteins was evaluated according to the method described above.

Methods for isolating a cell-free protein synthesizing system ( $S_{15}$ fraction) from rat liver and determining its activity are presented in the paper [12]. After decapitation and opening of the abdominal cavity, the liver through the inferior vena cava was perfused with medium comprising: $50 \mathrm{mM}$ Tris $\mathrm{HCl}$ (pH 7.6), $25 \mathrm{mM} \mathrm{KCl,} 5 \mathrm{mM} \mathrm{MgCl}, 0.25 \mathrm{M}$ sucrose. Then the liver was removed, crushed and homogenized in the same medium in a ratio of 1:2. The homogenate was centrifuged for $15 \mathrm{~min}$ at $15000 \mathrm{~g}$. The upper part of supernatant (fraction $\mathrm{S}_{15}$ ) was collected with removing the fat layer, if possible, and used in further experiments. All manipulations were carried out strictly in the cold.

The experiments were carried out in accordance with the Law of Ukraine "On Animals Protection Against Cruelty" (No. 3447-IV of February 21 ${ }^{\text {st, }}$ 2006, the rules of the Committee for Bioethics of the Institute for Problems of Cryobiology and Cryomedicine of the National Academy of Sciences of Ukraine, provisions of the "European Convention for the Protection of Vertebrates Animals Used for Experimental and Other Scientific Purposes".

We used glycerol and DMSO as penetrating CPAs, as well as non-penetrating CPA PEG-400 (MERCK, Germany). All of them were of chemically pure grade.

Gel filtration with Sephadex G-25. To remove CPAs from the incubation medium of the $\mathrm{S}_{15}$ fraction, it was filtered through a column containing Sephadex G-25 (coarse). For gel filtration of $2 \mathrm{ml}$ of the supernatant, a $1.8 \times 15 \mathrm{~cm}$ Sephadex G-25 column was prepared, which was stored in bi-distilled water at $4^{\circ} \mathrm{C}$ and filled with buffer solution before use. The sample was eluted with a buffer containing $30 \mathrm{mM}$ Tris $\mathrm{HCl}$ (pH 7.6), $5 \mathrm{mM} \mathrm{MgCl}$, and $110 \mathrm{mM} \mathrm{KCl}$.

Statistical analysis of experimental data was carried out using the software "Statgraphic plus for Windows" version 2.1. by Student's criterion. The results are presented as a mean obtained in a series of similar experiments (at least 6) and the standard deviation. The differences were considered significant at $P<0.05$.

\section{Results and Discussion}

It is known that the cryoprotective concentrations of the most commonly used CPAs such as DMSO and glycerol are $7.5-15 \%$ and $20-40 \%$, respectively $[1,14]$, and for poorly penetrating CPA 
PEG-400 it makes $15-20 \%[1,14]$. The cryopreserved cells are mainly pre-incubated with these CPAs at room temperature, that ensures a good permeability of cytoplasmic membranes and fast saturation of cells with CPAs $[1,14]$.

In the first series of experiments, we studied the effect of CPAs on protein biosynthesis in cells of lymphoid organs and liver within the concentration range providing a cryoprotective effect, as well as at low concentrations, which can be considered as remaining after washing of cells [8].

Fig. 1 demonstrates that after $15 \mathrm{~min}$ of incubation of thymus cells in a medium containing $0.5 \%$ glycerol, there was a tendency to inhibit an incorporation of ${ }^{14} \mathrm{C}$ amino acids into total proteins.

A further increase of glycerol content in the incubation medium of thymocytes to $2.5 \%$ or more leads to reliable and progressive inhibition of the inclusion of amino acids in the de novo synthesized proteins. At cryoprotective concentrations of glycerol of 15 and 20\% [1, 14], the incorporation of labeled amino acids into total proteins of thymocytes was only $12 \%$ and $3 \%$ versus an initial level, respectively (Fig. 1).

When studying the effect of DMSO on the ability of thymus cells to metabolize amino acids, it was found that the ability of cells to incorporate ${ }^{14} \mathrm{C}$-amino acids into the acid-insoluble fraction significantly decreases at $2.5-5 \%$ DMSO concentration in the incubation medium. At $10 \%$ DMSO concentration, which is most often used to cryopreserve the cells [1, 14], the level of incorporation of labeled amino acids decreased down to $30.4 \%$ of the control, and at $15 \%$ DMSO it reduced down to $14.5 \%$ versus the control (Fig. 1).

The incorporation of ${ }^{14} \mathrm{C}$-amino acids into total proteins of thymocytes turned out to be extremely sensitive to the action of PEG-400, which significantly suppressed this reaction even at $2.5 \%$ concentration and at $5 \%$ the inhibition of the process reached $63.6 \%$. When cells were incubated in a medium containing 20\% PEG-400, the level of incorporation of labeled amino acids into total thymocyte proteins made only $1.2 \%$ (Fig. 1).

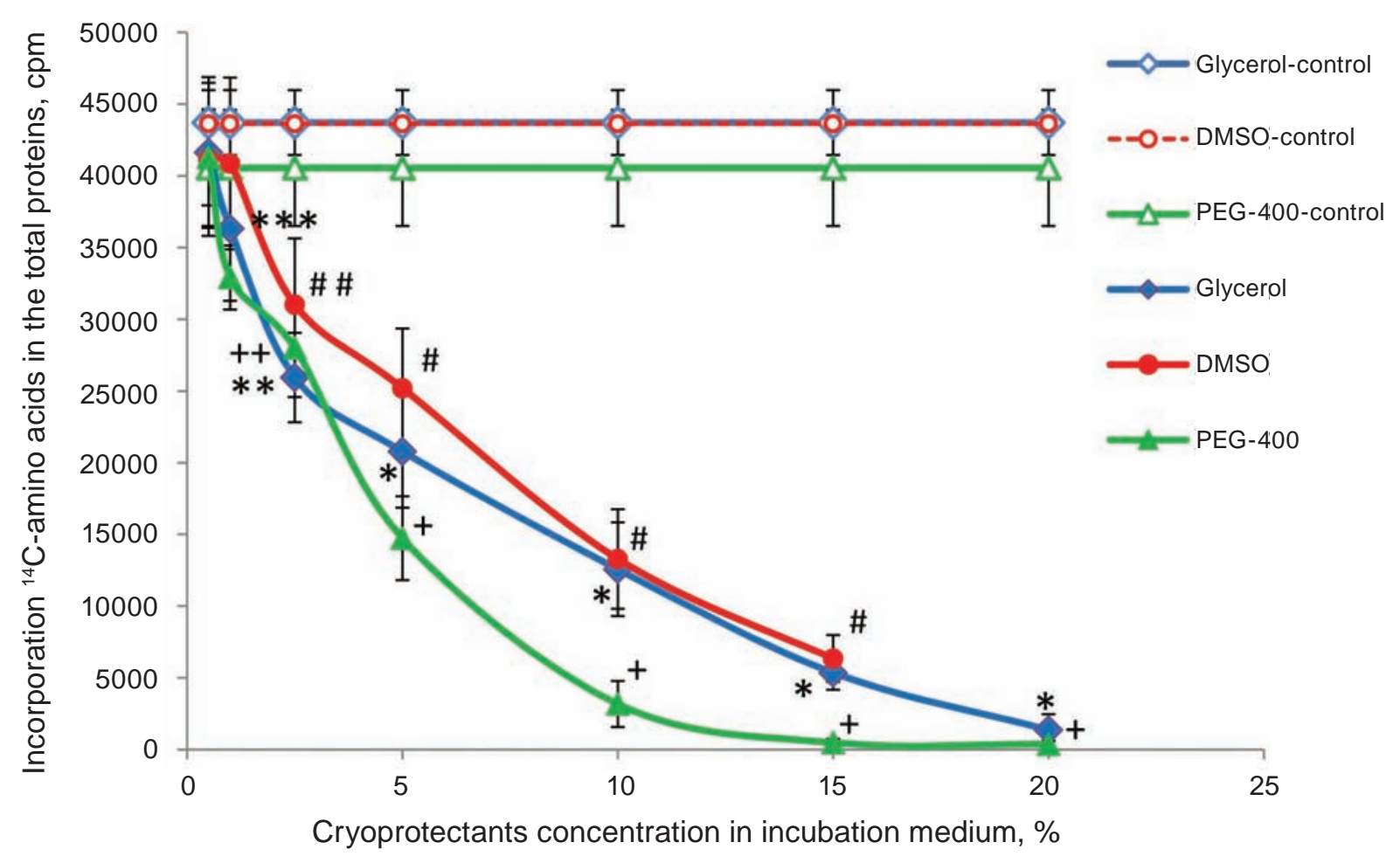

Fig. 1. Incorporation of ${ }^{14} \mathrm{C}$ amino acids into total proteins of thymocytes during incubation in media containing CPAs. Differences are significant if compared to the control for glycerol: $*^{*} P<<0.02,{ }^{*} P<<0.05, * P<0.001$; the differences are significant if compared with the control for DMSO: ${ }^{\#} P<0.01,{ }^{\#} P<0.001$; the differences are significant if compared with the control for $P E G-400:{ }^{++} P<0.01,{ }^{+} P<0.001$ 


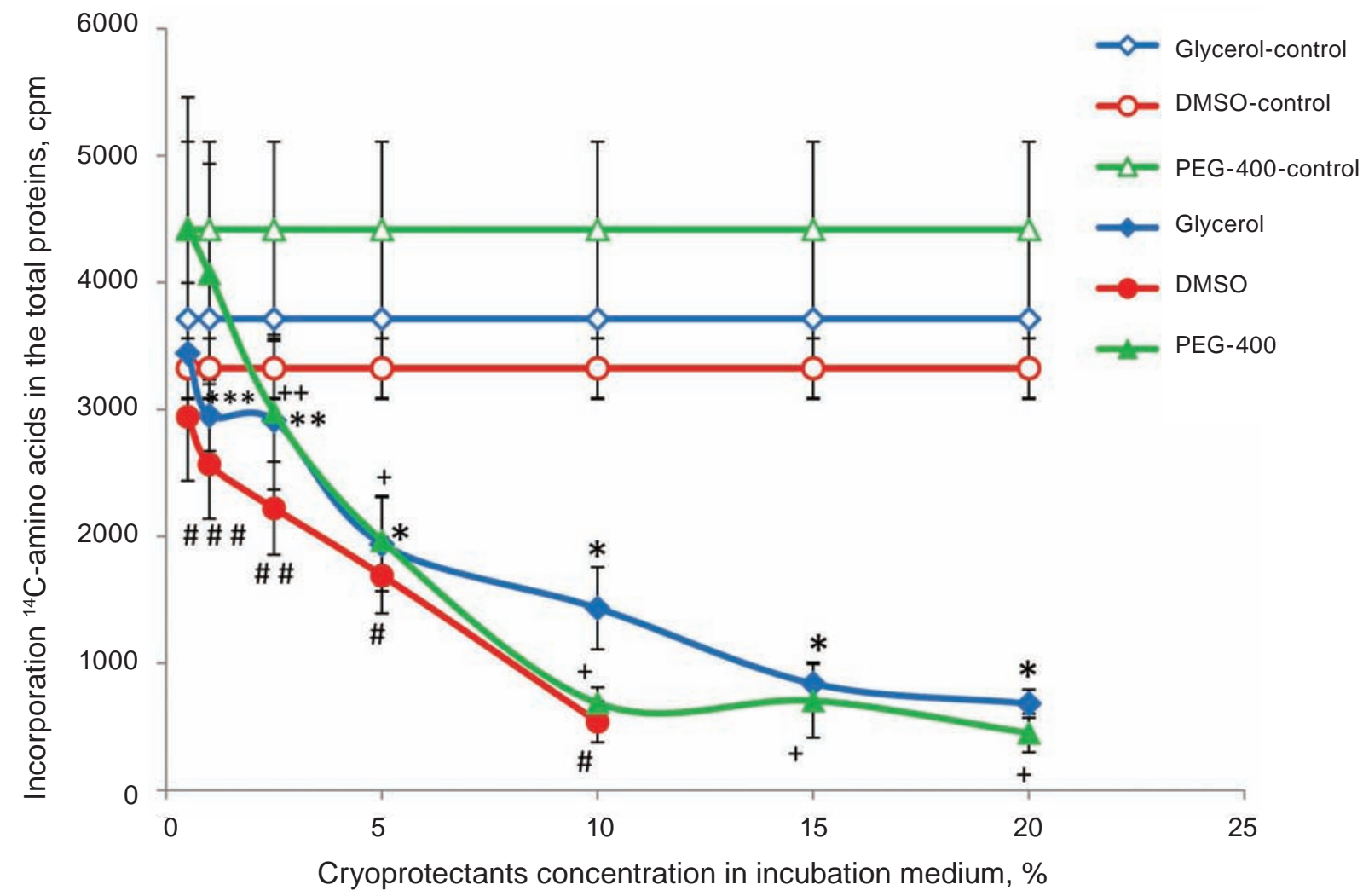

Fig. 2. Incorporation of ${ }^{14} \mathrm{C}$-amino acids into total proteins of lymph nodes cells during incubation in media containing CPAs. The differences are significant if compared with the control for glycerol: $* * * P<0.02$, ${ }^{* *} P<0.05,{ }^{*} P<0.001$; differences are significant if compared with control for DMSO: ${ }^{\# \#} P<0.05,{ }^{\# \#} P<0.01$, ${ }^{\#} P<0.001$; the differences are significant if compared with the control for $P E G-400:{ }^{++} P<0.01,{ }^{+} P<0.001$

Similarly, the studied CPAs affected the synthesis of proteins in cells of lymph nodes. This is confirmed by experimental data on the incorporation of ${ }^{14} \mathrm{C}$-amino acids into the acid-insoluble fraction (Fig. 2).

The data presented show that PEG-400 inhibits the protein biosynthesis more effectively. This is evident when comparing the molar concentrations of the studied CPAs. The level of incorporation of ${ }^{14} \mathrm{C}$-amino acids into total proteins of cells of lymph nodes at $15 \%$ concentration of glycerol in the incubation medium was reduced down to $22.6 \%$. When the content of DMSO in the incubation medium was $15 \%$, the inclusion of ${ }^{14} \mathrm{C}$-amino acids in the total proteins of the cells of the lymph nodes was practically absent. At a 15\% PEG-400 concentration in an incubation medium the test parameter decreased down to $15.9 \%$ if compared with the control.

The dynamics of incorporation of ${ }^{14} \mathrm{C}$-amino acids into total splenocyte proteins during incubation in media containing CPAs was similar to the above results. In particular, a strong decrease in the studied parameter was observed at a 5\% concentration of glycerol and DMSO or higher, as well as for PEG-400 at a concentration of $2.5 \%$ or higher.

With an increase in the concentration of glycerol, DMSO, or PEG-400 up to $15 \%$, the incorporation of ${ }^{14} \mathrm{C}$ amino acids into total splenocyte proteins relative to the control was $19.9 \%, 5.1 \%$, and $5.7 \%$, respectively (Fig. 3).

The results of investigating the CPA effect on incorporation of labeled amino acids into total proteins of liver cells (Fig. 4) demonstrate that under the influence of DMSO, the character of changes in the studied parameter was approximately the same as for lymphoid tissue cells. Strong inhibition of the process occurred with $10 \%$ DMSO in the incubation medium, i.e. $36.6 \%$ of the initial level.

PEG-400 inhibits more markedly the protein biosynthesis in liver cells. Its inhibitory effect was manifested starting with a 5\% concentration. At $10 \%$ PEG-400 in incubation medium, the incorporation of exogenous ${ }^{14} \mathrm{C}$-amino acids into the total proteins of rat liver cells decreased down to $21.1 \%$; at a con- 


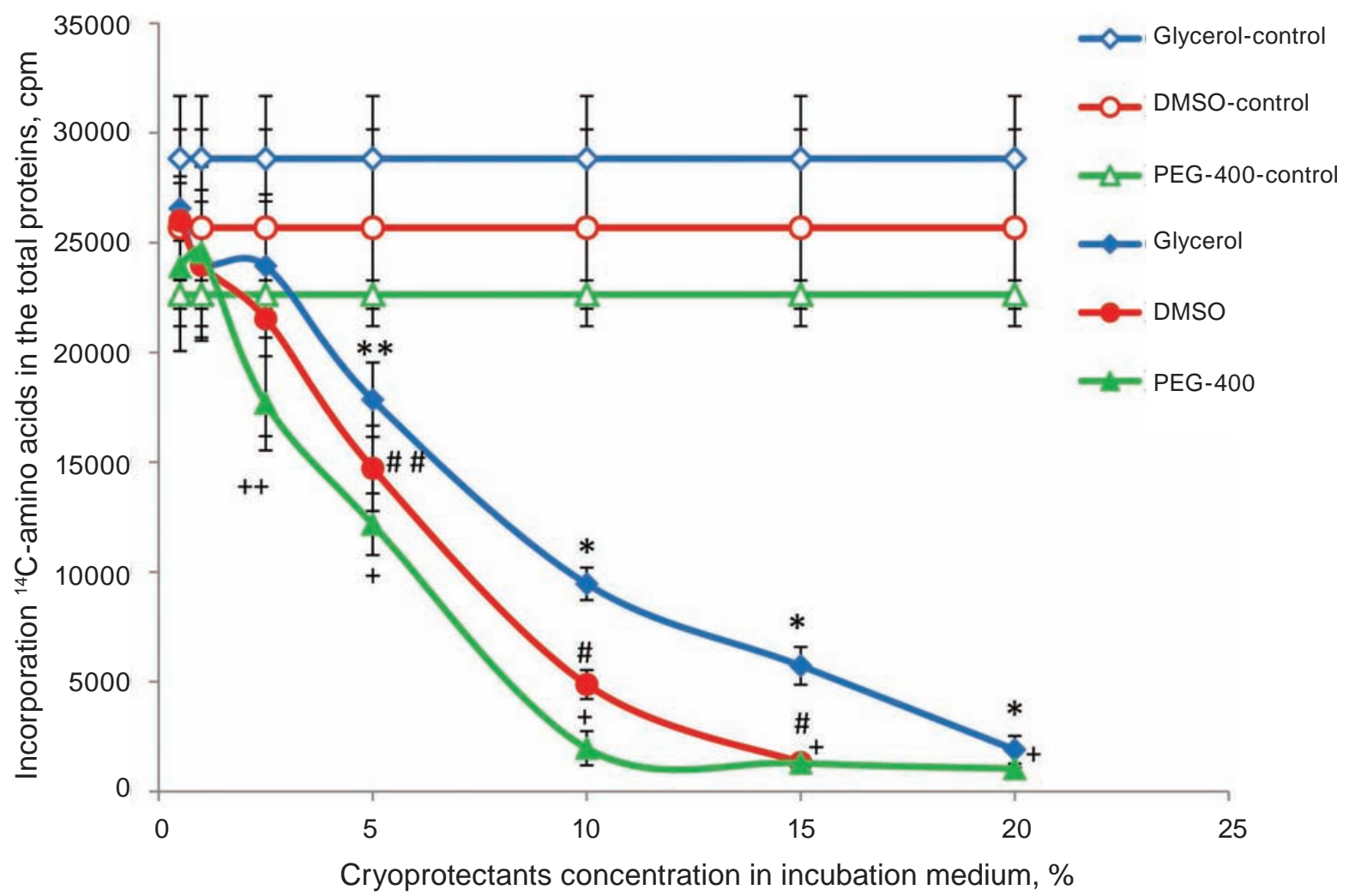

Fig. 3. Incorporation of ${ }^{14} \mathrm{C}$-amino acids into total proteins of splenocytes during incubation in media containing CPAs. Differences are significant if compared with the control for glycerol: ${ }^{* *} P<0.01, * P<0.001$; differences are significant if compared with the control for DMSO: ${ }^{\#} P<0.01,{ }^{\#} P<0.001$; the differences are significant if compared with the control for $P E G-400:{ }^{++} P<0.01,{ }^{+} P<0.001$

centration of $20 \%$, these values were reduced down to $3.6 \%$ versus the initial level.

In this case, an increase in the level of incorporation of ${ }^{14} \mathrm{C}$-amino acids into total proteins of rat liver sections was observed at low concentrations of PEG-400.

When studying the mechanisms of the above inhibitory effect of CPAs, in addition to their effect on the transport of amino acids and aminoacylation [12], an influence of penetrating CPAs directly on the structure and functions of ribosomes, including those in polyribosomes, as well as the components involved into aminoacylation, should not be excluded.

To verify our assumptions, we studied the effect of glycerol and PEG-400 on protein biosynthesis in a rat liver cell-free system. When investigating the dynamics of functioning of the protein synthesizing apparatus of a cell and its elements, it is necessary to take into account the role of $\mathrm{Mg}^{2+}$ ions, which crucially affect the protein biosynthesis. $\mathrm{Mg}^{2+}$ is known to be a cofactor of nucleotide-binding enzymes and guarantees the tRNA tertiary structure [15]. $\mathrm{Mg}^{2+}$ ions bind to each other subunits of ribosomes during protein biosynthesis [16]. $\mathrm{Mg}^{2+}$ also has been recognized as activating many enzymes; it is part of kinases that transfer the phosphate group from the ATP molecule to various substrates [17].

Our previous data showed [12] that low concentrations of CPAs enhanced the effect of $\mathrm{Mg}^{2+}$. Therefore, in this study, the effect of CPAs on protein synthesis in a cell-free system was examined using various concentrations of $\mathrm{Mg}^{2+}$ ions (Fig. 5, Table 1).

Analysis of the data presented in Fig. 5 reveals that the maximum incorporation of ${ }^{14} \mathrm{C}$-amino acids into the proteins synthesized in a cell-free system was shifted toward lower concetrations of $\mathrm{Mg}^{2+}$ with increasing concentration of PEG-400. In particular, if at an optimum concentration of $\mathrm{Mg}^{2+}$ in the incubation medium (5 mM), PEG-400 at a concentration of $13.2 \%$ reduced the incorporation of ${ }^{14} \mathrm{C}$-amino acids into the de novo synthesized proteins by about 


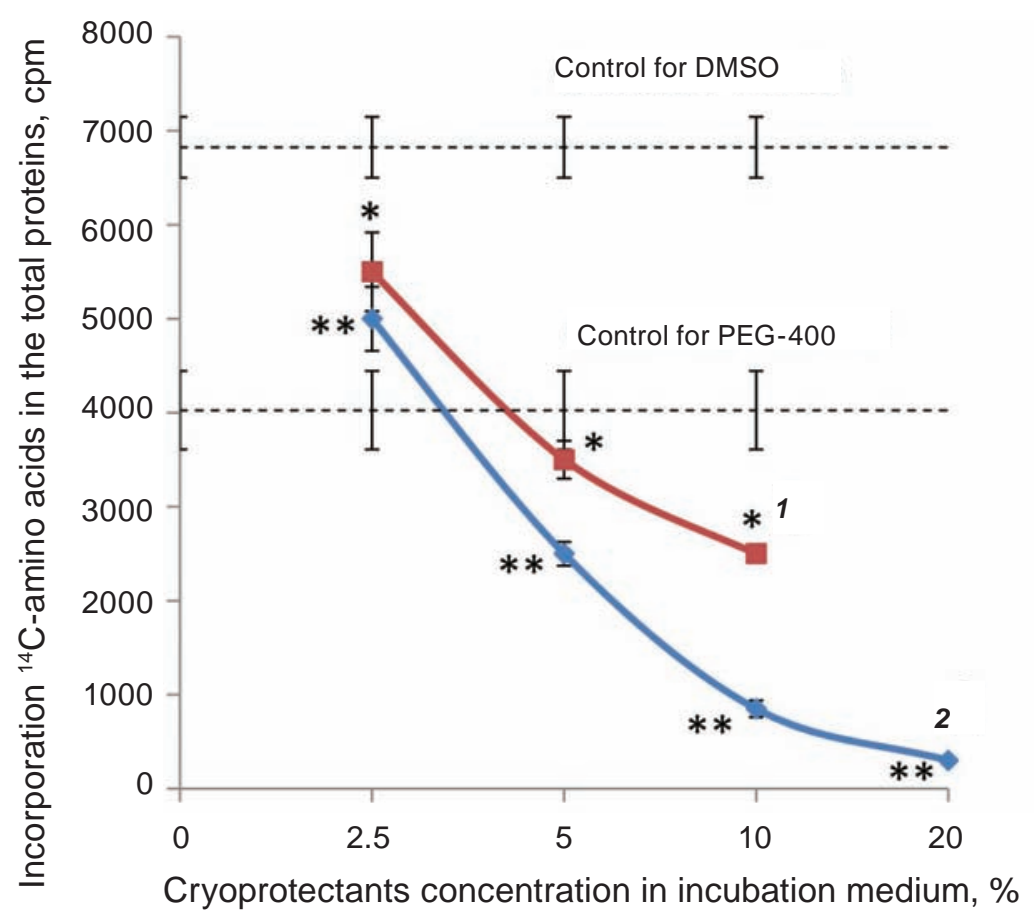

Fig. 4. Dependence of incorporation of ${ }^{14} \mathrm{C}$-amino acids into total cell proteins of rat liver slices at various concentrations of DMSO (1) or PEG-400 (2) in incubation medium. *Differences are significant if compared with the control for DMSO, $P<0.05$; **differences are significant if compared with the control for PEG-400, $P<0.05$

20.7 times, then a decrease in the $\mathrm{Mg}^{2+}$ content made it possible to almost completely restore this process (Fig. 5).

This regularity was less pronounced in the presence of glycerol added to the incubation medium at $40 \%$ concentration (Table 1 ).

So, if at $5 \mathrm{mM} \mathrm{Mg}^{2+}$ the protein biosynthesis in the postmitochondrial supernatant is inhibited by $67.2 \%$ of the initial level, then when the $\mathrm{Mg}^{2+}$ content decreases to $2 \mathrm{mM}$, the process was inhibited by $45.4 \%$. It should be noted that the level of ${ }^{14} \mathrm{C}$ Leu incorporation into total proteins of the rat liver post-mitochondrial supernatant $\left(\mathrm{S}_{15}\right)$ in $40 \%$ glycerol presence increased almost 2.5-fold with a decrease in the concentration of $\mathrm{Mg}^{2+}$ in the medium down to $1 \mathrm{mM}$ (Table 1).

When comparing an inhibitory effect of glycerol on protein biosynthesis and in a cell-free system this it can be found to be many times higher at a cell level. The fact discovered, most likely, indicates the role of amino acid transport in a mechanism of disruption of protein biosynthesis in cells under this CPA influence.

It is important to note that the inhibition of protein biosynthesis by CPAs in a cell-free system is reversible, as indicated by restoration of the studied index after a decrease in CPA concentration in the incubation medium (Table 2).

The presented results are consistent with data demonstrating the reversibility of the CPA action in studying their effect on the respiratory chain parameters [6].

Summarizing the results of experiments on the effect of CPAs on protein biosynthesis in a cell-free system, we suppose that in the mechanisms of inhi-

Table 1. Effect of glycerol and $\mathrm{Mg}^{2+}$ on protein synthesizing activity of rat liver post-mitochondrial supernatant $\left(S_{15}\right)$

\begin{tabular}{c|c|c}
\hline \multirow{2}{*}{$\begin{array}{c}\text { Concentration } \\
\text { of } \mathrm{Mg}^{2+}\end{array}$} & \multicolumn{2}{|c}{$\begin{array}{c}\text { Incorporation of }{ }^{14} \mathrm{C}-\text {-leucine } \\
\text { into total proteins, cpm }\end{array}$} \\
\cline { 2 - 3 } $\begin{array}{c}\text { incubation } \\
\text { media, mM }\end{array}$ & Control & $\begin{array}{c}\text { Glycerol 40\% } \\
(4.35 \mathrm{M})\end{array}$ \\
\hline 1 & $389 \pm 54$ & $994 \pm 109^{*}$ \\
2 & $8159 \pm 250$ & $4454 \pm 177^{*}$ \\
5 & $15083 \pm 737$ & $4953 \pm 386^{*}$ \\
\hline
\end{tabular}

Notes: differences are significant if compared to the control, $P<0.001$ 

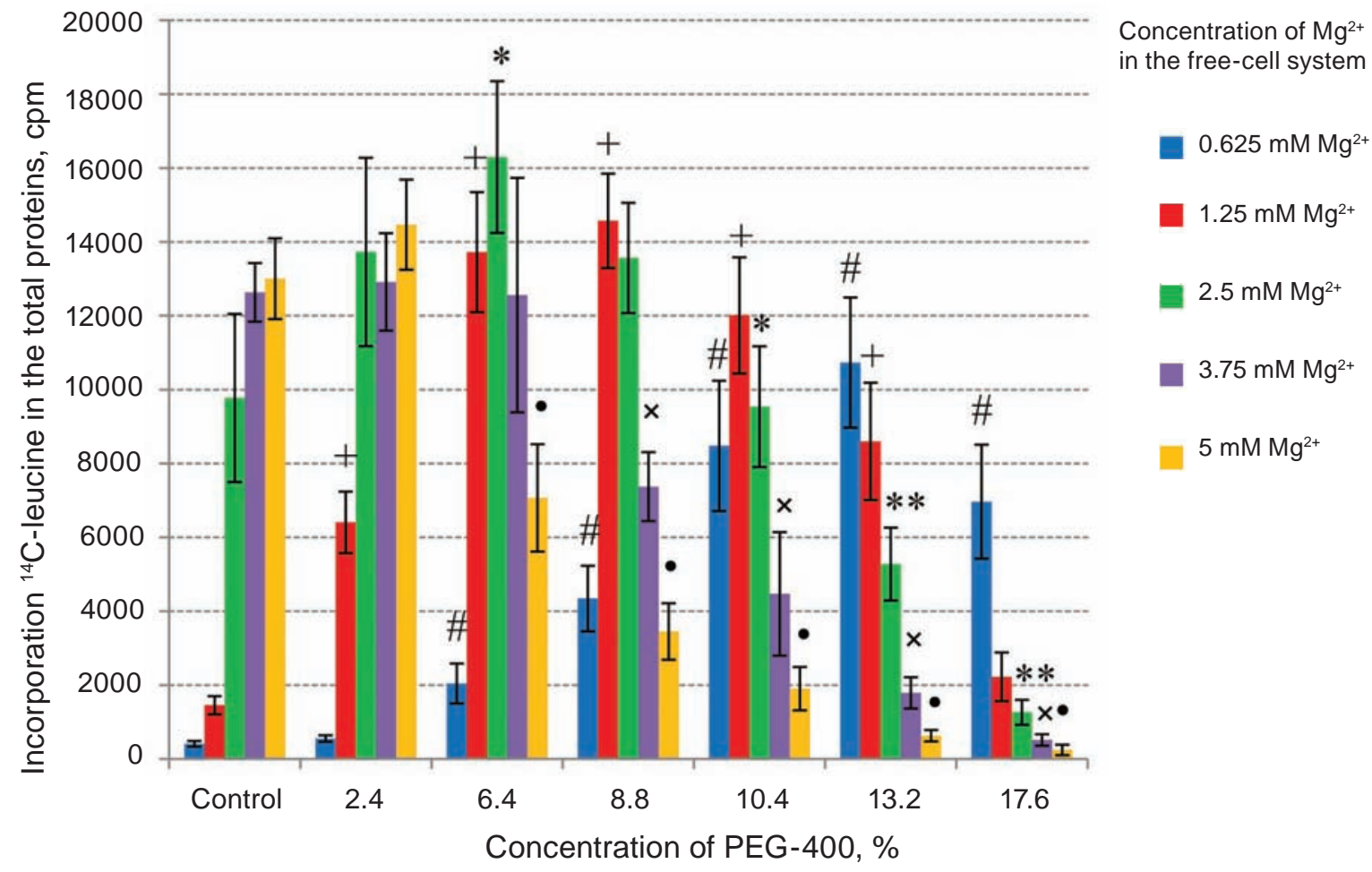

Fig. 5. Protein synthesizing activity of rat liver postmitochondrial supernatant (S15) depending on concentration of $\mathrm{Mg}^{2+}$ and PEG-400 in incubation medium. Differences are significant if compared with the control for $0.625 \mathrm{mM} \mathrm{Mg}{ }^{2+}:{ }^{\#} \mathrm{P}<0.001$; differences are significant if compared with the control for $1.25 \mathrm{mM} \mathrm{Mg}^{2+}$ : ${ }^{+} P<0.001$; differences are significant if compared with the control for $2.5 \mathrm{mM} \mathrm{Mg}{ }^{2+}:{ }^{*} P<0.02,{ }^{* *} P<0.001$; differences are significant if compared with the control for $3.75 \mathrm{mM} \mathrm{Mg}^{2+}:{ }^{\times} \mathrm{P}<0.001$; differences are significant if compared with the control for $5 \mathrm{mM} \mathrm{Mg}^{2+}: \cdot P<0.001$

Ta b le 2. Protein synthesizing activity of rat liver postmitochondrial supernatant $\left(S_{15}\right)$ after removal of CPAs from incubation medium

\begin{tabular}{l|c|c|c}
\hline $\begin{array}{c}\text { CPA type during } \\
\text { incubation with } \mathrm{S}_{15}\end{array}$ & $\begin{array}{c}\text { Content in incubation } \\
\text { medium }\end{array}$ & $\begin{array}{c}\text { Incorporation of }{ }^{14} \text { C-leucine } \\
\text { into total proteins after } \\
\text { removal of CPAs, cpm }\end{array}$ & $\begin{array}{c}\text { Comparison with } \\
\text { the control,\% }\end{array}$ \\
\hline Control & - & $4575 \pm 276$ & - \\
Glycerol & $40 \%(4.35 \mathrm{M})$ & $4668 \pm 801$ & 102 \\
PEG-400 & $22.5 \%(0.56 \mathrm{M})$ & $4247 \pm 1136$ & 89 \\
\hline
\end{tabular}

Notes: $\mathrm{Mg}^{2+}$ concentration in incubation medium is $5 \mathrm{mM}$. CPAs were removed from incubation medium by gel filtration with a Sefadex G-25 column

bition of protein biosynthesis at a cell level, in addition to blocking the membrane transfer of amino acids, molecular rearrangements of the translation apparatus under the influence of CPA are of great importance.

This assumption is confirmed with the reports $[18,19]$, which demonstrated that organic solvents with the properties of CPA, in particular methanol, ethanol, DMSO, etc., contributed to the $\mathrm{Mg}^{2+}$ - dependent stabilization of ribosomes in associated state, as well as altered activity of aminotransferases and other translation factors, which generally reduced the translation apparatus functional activity. The decrease in the translation apparatus functional activity can also be associated with the interaction of cryoprotective agents with nucleotide bases of various types of RNA, as was reported [20]. 
Considering the possible mechanisms of the observed phenomenon of inhibition of protein synthesis in cells and cell-free systems, we can assume that they are primarily based on a change in the physicochemical properties of water, in particular its structural state and dielectric constant [21-23], accompanied by strengthening of hydrogen bonds [21, 22], which are important in interaction of metabolites with their carriers, as well as functioning of ribosomes and enzymes involved into the translation. Apparently, an increase in the concentration of electrolytes, including $\mathrm{Mg}^{2+}$, is also crucial, as a result of a decrease in the free water fraction due to its binding to cryoprotective agent molecules.

In addition to the certain interest for cryobiology, we believe that the performed studies out are of general biological fundamental value, since the data indicate the possibility of protein synthesis in mixed solvents under conditions of an altered structure of water.

Thus, the following conclusions can be drawn as a result of the experiments:

1. Glycerol, DMSO and PEG-400 at cryoprotective concentrations significantly inhibit protein biosynthesis in the thymus, spleen, lymph nodes and liver cells. PEG-400 polymeric CPA revealed the most effective inhibitory effect.

It is important to note that, in a cell-free system the PEG-400 CPA in low concentrations, probably remaining in cells and tissues after washing, contributes to an increase in protein synthesis intensity. Similar results were obtained in experiments on whole cells as part of liver slices.

2. An inhibitory effect on protein biosynthesis in the studied cells was found to be due to a direct influence of these CPAs on the translation apparatus.

3. An inhibitory effect of CPA on the protein synthesizing apparatus of cells was found to be $\mathrm{Mg}^{2+}$-dependent in nature, and the inhibitory effect itself was reversible.

Conflict of interest. Authors have completed the Unified Conflicts of Interest form at http://ukrbiochemjournal.org/wp-content/uploads/2018/12/ coi_disclosure.pdf and declare no conflict of interest.

Funding. The work was financed from the budget of the Academy of Sciences of Ukraine. State Registration Numbers: No 2.2.6.4.

\section{ВПЛИВ КРІОПРОТЕКТОРІВ НА ВКЛЮЧЕННЯ АМІНОКИСЛОТ В ЗАГАЛЬНІ ПРОТЕЇНИ В КЛІТИНАХ ЛІМФОЇДНИХ ОРГАНІВ І ПЕЧІНКИ ЕКСПЕРИМЕНТАЛЬНИХ ТВАРИН}

\author{
О. К. Гулевський , Ю. С. Ахатова, \\ А. Ю. Нікольченко
}

\author{
Інститут проблем кріобіології і \\ кріомедицини НАН України, Харків; \\ ॠe-mail: profgulevskyy@gmail.com
}

Досліджено вплив проникних (гліцерин, ДМСО) і слабопроникних (ПЕГ-400) кріопротекторів на включення мічених амінокислот у синтезовані de novo протеїни в клітинах тимуca, лімфатичних вузлів, селезінки та в безклітинному екстракті печінки миші. Встановлено, що кріопротектори в діапазоні концентрацій, за яких спостерігається кріозахисний ефект, вірогідно пригнічують синтез протеїнів у досліджуваних клітинах. Найефективнішу пригнічувальну дію чинив полімерний кріопротектор ПЕГ-400. Виразніше пригнічення синтезу протеїнів кріопротектори спричиняли на клітинному рівні, що, очевидно, пов'язано з їх впливом на систему транспорту амінокислот. Визначено, що інгібувальна дія кріопротекторів на біосинтетичний апарат клітин $\epsilon \mathrm{Mg}^{2+}$-залежною та оборотною.

К л ю ч о в і с л о в а: кріопротектори, включення амінокислот, біосинтез протеїнів, безклітинна система, лімфоїдні органи, $\mathrm{Mg}^{2+}$-залежна дія кріопротекторів.

\section{References}

1. Best BP. Cryoprotectant toxicity: facts, issues, and questions. Rejuvenation Res. 2015; 18(5): 422-436.

2. Elliott GD, Wang S, Fuller BJ. Cryoprotectants: A review of the actions and applications of cryoprotective solutes that modulate cell recovery from ultra-low temperatures. Cryobiology. 2017; 76: 74-91.

3. Baust JG, Baust JM, Shnayder K, Van Bascirk R. Biopreservation - molecular-based mitigation of the preservation challenges. Probl Cryobiol. 2008; 18(2): 163. (In Russian). 
4. Gulevsky AK, Lavrik AA, Trifonova AV. The Influence of DMSO and a fraction (below $5 \mathrm{Kda}$ ) from cord blood on MSC culture growth. Bull Probl Biol Med. 2014; 3(112): 96-99. (In Russian).

5. Dyubko TS. Interaction of cryoprotectants with model membranes with high cholesterol content. Probl Cryobiol. 2006; 16(3): 271-285. (In Russian).

6. Nardid OA. Study of low-molecular effect of cryoprotectants on mitochondria respiratory chain by spin probe EPR. Probl Cryobiol. 2009; 19(2): 177-185. (In Russian).

7. de Ménorval MA, Mir LM, Fernández ML, Reigada R. Effects of dimethyl sulfoxide in cholesterol-containing lipid membranes: a comparative study of experiments in silico and with cells. PLoS One. 2012; 7(7): e41733.

8. Verheijen M, Lienhard M, Schrooders Y, Clayton O, Nudischer R, Boerno S, Timmermann B, Selevsek N, Schlapbach R, Gmuender H, Gotta S, Geraedts J, Herwig R, Kleinjans J, Caiment F. DMSO induces drastic changes in human cellular processes and epigenetic landscape in vitro. Sci Rep. 2019;9(1):4641.

9. Kang MH, Das J, Gurunathan S, Park HW , Song H, Park C, Kim JH. The cytotoxic effects of dimethyl sulfoxide in mouse preimplantation embryos: a mechanistic study. Theranostics. 2017; 7(19): 4735-4752.

10. Zhou D, Shen X, Gu Y, Zhang N, Li T, Wu X, Lei L. Effects of dimethyl sulfoxide on asymmetric division and cytokinesis in mouse oocytes. BMC Dev Biol. 2014;14:28.

11. Gulevsky AK, Grischenkova EA. Structural and functional changes in the transport system of glycine in the cryopreservation process. I Proc. of scientific papers "Biochemical aspects of cryogenic damage and cryoprotection of adhesive systems“, Kharkov. 1989: 38-41. (In Russian).

12. Gulevsky AK, Nikolchenko AYu. The influence of the penetrating cryoprotectors on protein synthesis in the cell-free system of the rat liver. Ukr Biokhim Zhurn. 2012; 84(5): 68-75. (In Russian).
13. Umbreit VV, Burris RKh, Shtrauffur J. Manometric methods for studying tissue metabolism. Moscow: Foreign. lit. 1951. 153 p. (In Russian).

14. Belous AM, Gryshchenko VI. Cryobiology. Kiev: Naukova Dumka, 1994. 431 p. (In Russian).

15. Roush RF, Nolan EM, Löhr F, Walsh CT. Maturation of an Escherichia coli ribosomal peptide antibiotic by ATP-consuming N-P bond formation in microcin C7. J Am Chem Soc. 2008; 130(11): 3603-3609.

16. Ben-Shem A, Jenner L, Yusupova G, Yusupov M. Crystal structure of the eukaryotic ribosome. Science. 2010; 330(6008): 1203-1209.

17. Spirin AS. Molecular biology. Ribosomes and protein biosynthesis. M.: Akademiya, 2011. 496 p. (In Russian).

18. Petermann ML, Pavlovec A, Hamilton MG. Effects of agents that influence hydrogen bonding on the structure of rat liver ribosomes. Biochemistry. 1972; 11(21): 3925-3933.

19. Spirin AS. The structure of the ribosome and protein biosynthesis. Pushchino: Sci. center biol. researches of USSR Academy of Sciences, 1984. 367 p. (In Russian).

20. Venkataramanan NS, Suvitha A, Kawazoe Y. Intermolecular interaction in nucleobases and dimethyl sulfoxide/water molecules: A DFT, NBO, AIM and NCI analysis. $J$ Mol Graph Model. 2017; 78: 48-60.

21. Yang B, Cao X, Wang C, Wang S, Sun C. Investigation of hydrogen bonding in Water/ DMSO binary mixtures by Raman spectroscopy. Spectrochim Acta A Mol Biomol Spectrosc. 20205; 228: 117704.

22. Titova AG, Zaychikov AM. Hydrogen bonds in complexes of ethylene glycol, monoethanolamine and ethylene diamide with water. J Phys Chem. 2017; (2): 114-118.

23. Daschakraborty S. How do glycerol and dimethyl sulphoxide affect local tetrahedral structure of water around a nonpolar solute at low temperature? Importance of preferential interaction. J Chem Phys. 2018; 148(13): 134501. 